\title{
New species of Stenocrates from Brazil (Coleoptera: Scarabaeidae)
}

\author{
Brett C. Ratcliffe $\left({ }^{\star}\right)$
}

\begin{abstract}
Six new species of Stenocrates (Scarabaeidae: Dynastinae) are described from the Amazon Basin of Brazil: S. rionegroensis, S. varzeaensis, S. inpai, S. amazonicus, S. ariasi, and S. laceyi. The females of S. haackae Ratcliffe and S. popei Endrödi are reportd for the first time and briefly characterized. Stenocrates popei is listed from Brazil and constitutes a new country record.
\end{abstract}

The New World cyclocephaline genus Stenocrates was revised by Endrödi (1966) who recognized 20 species at that time. Endrödi (1967, 1969 ,1971, 1973) has since described five additional species, and Ratcliffe (1977) described two. Six new species from Brazilian Amazonia are described here resulting in a total of 33 species in the genus. It would appear that the high species diversity of Stenocrates observed just in the Amazon Basin (about $60 \%$ of the genus) combined with the high degree of intraspecific similarity in external gross morphology suggests an evolutionarily young genus in the process of active speciation and expansion. Furthermore, given the surprisingly poor record of adequate collecting in the vastness of the Amazon region, I believe it is a certainty that additional new Stenocrates will be found as a result of further collecting. The existing trend supports this latter view, i. e., approximately $60 \%$ of the Amazonian species of Stenocrates have been described since 1966 .

The new species described here are presented in a manner enabling easy identification. The description of puncture size and depth follows my earlier usage (Ratcliffe, 1975. 1977).

\section{Stenocrates rionegroensis, new species (Figs, 1-2)}

TYPE MATERIAL - Holotype male, labeled "Brasil: Amazonas, $127 \mathrm{~km}$ ONO (WNW) de de Manaus, 12-1-1978, Norman D. Penny". Allotype fema!e, one male paratype, and one female paratype with same data. Types deposited at the Instituto Nacional de Pesquisas da Amazônia (INPA). Paratypes deposited at INPA and in the Brett $C$. Ratcliffe collection (BCRC) .

HOLOTYPE - Male. Length $20.5 \mathrm{~mm}$; greatest width $11.0 \mathrm{~mm}$. Color black; apex of clypeus and elytra very dark piceous. Head: Front sparsely punctate; punctures small to moderate mixed, shallow. Interocular width 2.5 transverse eye diameters as seen from above. Frontoclypeal suture wide (widest at middle), deep. Clypeus trapezoidal, narrowing apically, sides nearly straight, apex truncate, margins reflexed; surface weakly rugo-punctate. Pronotum: Length-width ratio 2:3. Surface sparsely and feebly aciculate, irregularly punctate except on center of disc and near anterior margin which are virtually impunctate; punctures small to large (large either side of disc and near basal angles), shallow to moderately deep, ocellate, some weakly umbilicate. Scutellum triangular, impunctate. Elytra: Discal area with 8 rows of punctures; punctures large, moderately deep, ocellate (most with ring of puncture c-shaped, open posteriorly). Row 1 (next to suture) with punctures in a single line, some confluent (especially apically); row 2 broad, punctures not in a single line but irregular; rows $3-4$ regularly punctate, closely adjacent; row 5 narrow, only 3 punctures in basal half, nearly regularly punctate, in apical half; rows 6-7 regularly punctate, closely adjacent, arcuate; row 8 about half as wide as row 2 , irregualrly punctate. Sides similar to disc; 2 regular rows of punctures behind humerus, followed laterally by a row of irregular punctures, 2 rows of regular punctures, and a row of irregular punctures next to lateral margin. Pygidium: Surface densely punctate; punctures large, moderately deep, ocellate (round medially to c-shaped laterally), weakly umbilicate. Genitalia: Figs. 1-2.

$\left({ }^{\bullet}\right)$ - Instituto Nacional de Pesquisas da Amazônia, Manaus. 
ALLOTYPE - Female. Length $22.0 \mathrm{~mm}$; greatest width $12.0 \mathrm{~mm}$. As holotype except in the following respects: Head: Front with punctures slightly larger. Frontoclypeal suturc not as deep, slightly arcuate. Clypeus a little more rugose. Pronotum: Center of disc and anterior margin with small, shallow punctures. Elytra: Row 5 impunctate in basal fourth, regularly punctate in second quarter, then irregularly punctate. Pygidium: Punctures more distinctly umbilicate.

VARIATION - Males (1 paratype): Length $20.5 \mathrm{~mm}$; greatest width $11.0 \mathrm{~mm}$. Head: Front with punctures slightly larger. Pronotum: Center of disc with a few small punctures. Elytra: Row 2 sparsely punctate basally; row 5 with 4 punctures in apical fifth only, otherwise impunctate; row 8 impunctate at middle.

Females (1 paratype): Length $21.0 \mathrm{~mm}$; greatest width $12.0 \mathrm{~mm}$. Head: Front with punctures smaller than in allotype. Elytra: Row 5 impunctate in basal half.

DIscussion - The parameres of the male genitalia of this species are nearest those of Stenocrates difficilis Endrödi, but vary significantly in the shape and proportion of the shatt and apical lobes. In addition, the frontoclypeal suture in S. difficilis is very shallow (Endrödi, 1966) whereas it is quite deep in S. rionegroensis. These differences will separate the two species easily.

The four specimens were taken at black light on a boat moored close to shore in an area of varzea forest (swamp or inundation forest) along the Rio Negro.

ETYMOLOGY - This species is named after the river on which it was taken, the Rio Negro.

\section{Stenocrates varzeaensis, new species} (Figs, 3-4)

TYPE MATERIAL - Holotype male, labeled Brasil: Amazonas, Taruma-Manaus, 10-IX-24IX-1971, U. Irmler." Allotype female with same locality data, but with date of 29-X-19-XI-1971. Single male paratype also with same locality data, but with date of 19-XI-4-XII-1971. Types depcsited at the Instituto Nacional de Pesquisas da Amazônia (INPA). Paratype deposited in the Brett C. Ratcliffe collection (BCRC).
HOLOTYPE - Male. Length $18.5 \mathrm{~mm}$; greatest width $10.0 \mathrm{~mm}$. Color black. Head: Front very feebly punctate; punctures sparse, minute to small, shallow. Interocular width about 5 transverse eye diameters as seen from above. Frontoclypeal suture a distinctly impressed line laterally; middle deep, broad, angulate. Clypeus trapezoidal, narrowing apically, sides gently curved (not straight), apex truncate margins reflexed; surface weakly punctate except apex which is feebly rugopunctate; punctures sparse, small, shallow. Pronotum: Length-width ratio 2.5:4. Surface aciculate, irregularly punctate; punctures small to large (large near posterior angles), shallow to moderately deep, larger punctures ocellateumbilicate. Scutellum triangular, impunctate. Elytra: Discal area with 8 rows of punctures; punctures moderate to large, moderately deep, weakly ocellate (some c-shaped, ring open posteriorly), some weakly umbilicate. Row 1 (next to suture) with punctures in a single line, punctures becoming confluent near middle, changing to an impressed groove apically; row 2 broad, punctures irregular; rows 3-4 regularly punctate, closely adjacent; row 5 half as wide as row 2, impunctate in basal $2 / 3$, irregularly punctate in apical third; rows 6-7 regularly punctate, closely adjacent, arcuate: row 8 a little wider than row 5 , irregularly punctate, many punctures confluent. Sides with 2 regular rows of punctures behind humerus, followed laterally by a broad row of irregular punctures, 2 indistinct rows of regular punctures, and a row of irregular punctures next to lateral margin. Pygidium: Surface densely punctate; punctures large, moderately deep, ocellate (c-shaped laterally). Genitalia : Figs. 3-4.

ALLOTYPE - Female. Length $20.0 \mathrm{~mm}$; greatest width $10.5 \mathrm{~mm}$. Differs little from holotype except in the following respects: Head: Interocular width slightly larger, about 5.5 transverse eye diameters as seen trom above. Elytra: Row 5 with only a few punctures apically; row 8 lacking numerous confluent punctures.

VARIATION - The single male paratype does not differ significantly from the holotype. It is missing the right metathoracic leg. 
DISCUSSION - The male genitalia for this species are diagnostic, and, therefore, S. varzeaensis is readily separated from all other species in the genus.

This species, like $S$, rionegroensis, was taken in an area of varzea or inundation forest near the Rio Negro. These specimens were collected in pitfall traps using a $4 \%$ formalin solution, and were taken as part of a larger project studying inundation forest invertebrates conducted by Ulrich Irmler of the MaxPlanck Institute.

ETYMOLOGY - S. varzeaensis is named using the Brazilian word for the type of forest in which it was collected, varzea.

\section{Stenocrates inpai, new species (Figs. 5-6)}

TYPE MATERIAL - Holotype male, labeled "Resreva Ducke, Manaus, Amazonas, Brasil.". Date and name of collector lacking. Type deposited at the Instituto Nacional de Pesquisas da Amazônia (INPA).

HOLOTYPE - Male. Length $17.5 \mathrm{~mm}$; greatest width $10.0 \mathrm{~mm}$. Color black dorsally, venter completely dark piceous. Head: Front rugo-punctate. Interocular width 2.5 transverse eye diameters as seen from above. Frontoclypeal line a distinct, slightly curved ridge (not an impressed sutural line as in previous 2 species). Clypeus trapezoidal, narrowing apically, sides slightly curved, apex truncate, margins reflexed; surface rugo-punctate. Pronotum: Length-width ratio 2.5:4. Surface minutely aciculate, irregularly punctate; punctures small to large (large either side of disc and near apical and basal angles), shallow to moderately deep, ocellate, weakly umbilicate. Scutellum triangular, impunctate. Elytra: Discal area with 8 rows of punctures; punctures large, moderately deep, ocellate (most c-shaped, ring open behind). Row 1 (next to suture) with puncutres in a single line, puncutes becoming confluent at apex; row 2 broad, irregularly punctate except at base which is impunctate; rows 3-4 regularly punctate, closely adjacent; row 5 nearly as broad as row 2 , simpunctate except in apical fourth which has 8 punctures in a single file; rows 6-7 regularly punctate, closely adjacent, arcuate; row 8 subequal to row 5 in width with several punctures in a straight line. Sides similar to disc; 2 regular rows of punctures behind humerus, followed laterally by a row of irregular punctures, 2 indistinct rows of regular punctures, and a row of irregular punctures next to lateral margin. Pygidium: Surface densely punctate; punctures large, moderately deep, round to oval, ocellate, some umbilicate. Genitalia: Figs. 5-6.

DISCUSSION - The male genitalia of $S$. inpai most closely resemble those of $S$. omissus Endrödi in general appearance, but the parameres are very distinctive, especially in lateral view.

The single example was taken at Reserva Ducke which is an INPA forest reserve $26 \mathrm{~km}$ NE of Manaus on BR 010; it was probably collected during the late 1960's. Subsequent collecting at the reserve during the past year and a half failed to yield further specimens.

ETYMOLOGY - Stenocrates inpai is named after the acronym for the Instituto Nacional de Pesquisas da Amazônia in Manaus.

\section{Stenocrates amazonicus, new species (Figs, 7-8)}

TYPE MATERIAL - Holotype male, labeled "Brasil: Amazonas, Urucurituba, II-14-1977, P. Ramos". Type deposited at the Instituto Nacional de Pesquisas da Amazônia (INPA).

HOLOTYPE - Male. Length $19.0 \mathrm{~mm}$; greatest width $10.5 \mathrm{~mm}$. Color black dorsally, dark piceous ventrally. Head: Front densely punctate; punctures small to moderately large, shallow. Interocular width 2.5 transverse eye diameters as seen from above. Frontoclypeal suture broad, shallow. Clypeus trapezoidal, narrowing apically, sides very weakly curved, apex truncate, margins reflexed; surface transversely rugose. Pronotum: Length-width ratio $2: 3$. Surface very sparsely aciculate, irregularly punctate; punctures small to large (large either side of middle and near basal angles), moderately deep, ocellate, weakly umbilicate. Scutellum triangular, impunctate. Elytra: Discal area with 8 rows of punctures; punctures large, moderately deep, most ocellate (c-shaped, open behind). Row 1 (ad- 

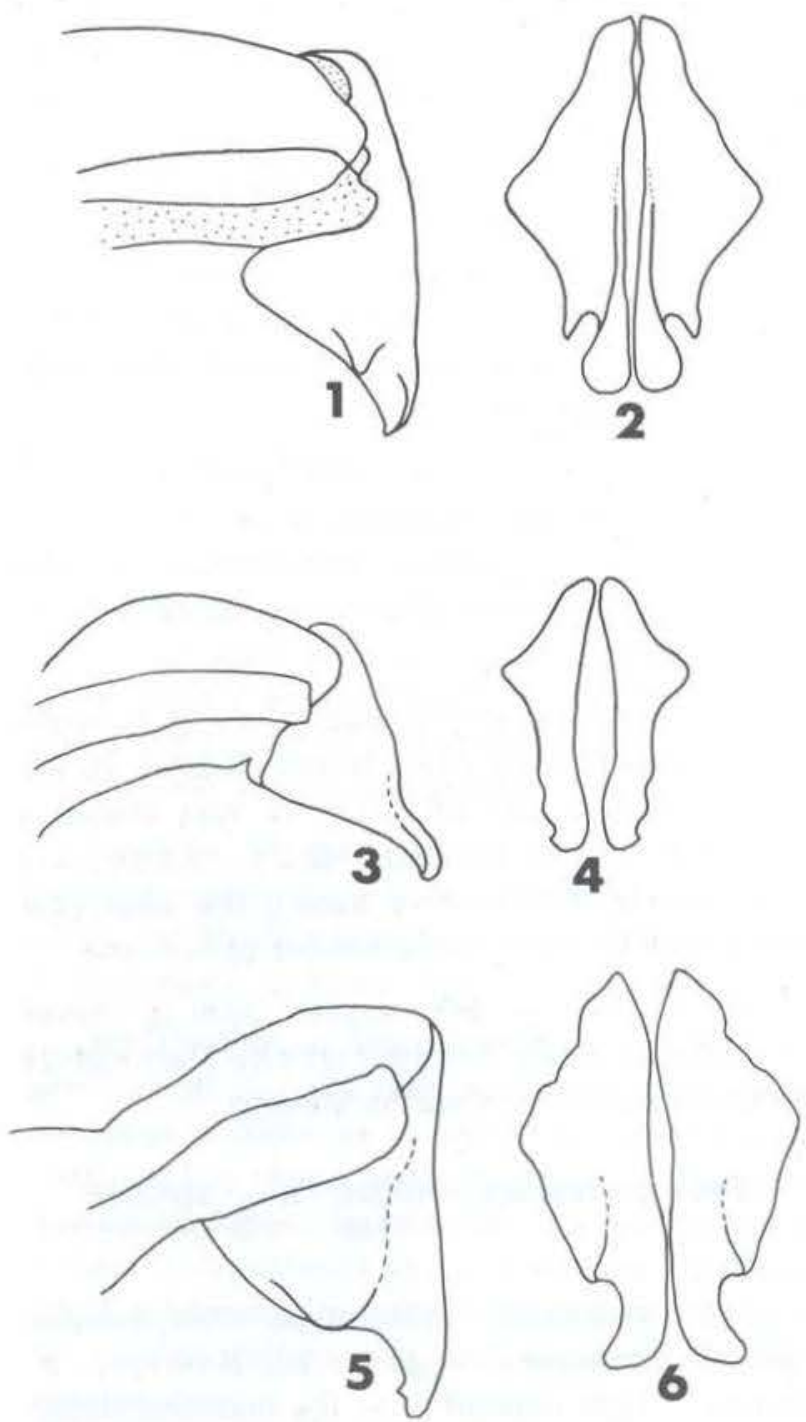

Figs, 1-6 - Lateral and caudal views of male genitalia. Figs. 1-2 - Stenocrates rionegroensis. Figs. $3-4-$ S. varzeaensis. Figs. $5-6-\mathrm{S}$ inpai.

jacent to suture) regularly punctate; punctate; row 2 broad, irregularly punctate; rows 3-4 regularly punctate, closely adjacent; row 5 impunctate except at apex which has a few punctures, about half as wide as row 2; rows 6-7 regularly punctate, closely adjacent, arcuate; row 8 subequal in width to row 5 , regularly punctate at apex, irregularly punctate just before midpoint, otherwise impunctate. Sides similar to disc; 2 regular rows of punctures behind humerus, followed laterally by a row of irregular punctures, 2 rows of regular punctures, and a row of irregular punctures next to lateral margin. Pygidium: Surface densely punctate; punctures large, moderately deep, ocellate-umbilicate (round medially, c-shaped laterally). Genitalia: Figs. 7-8.

DISCUSSION - The parameres of the male genitalia are unlike those of any other species in the genus and will serve to easily separate this species.

ETYMOLOGY - Stenocrates amazonicus is named after the region in which it occurs.

\section{Stenocrates ariasi, new species} (Figs, 9-10)

TYPE MATERIAL - Holotype male, labeled "Estirão do Ecuador, Rio Javari, Amazo. Brasil, XI-1960, J. Hidasi". Allotype female, one male paratype, and two female paratypes with same data. Types deposited at the Instituto Nacional de Pesquisas da Amazônia (INPA). Paratypes deposited at the Museu Paraense Emílio Goeldi (MPEG) in Belém, the Museu de Zoologia da Universidade de Săo Paulo (MZSP), and in the Brett C. Ratcliffe collection (BCRC).

HOLOTYPE - Male. Length $20.5 \mathrm{~mm}$; greatest width $11.0 \mathrm{~mm}$. Color black. Head: Front sparsely punctate; punctures very small, shallow. Interocular wijth 3.0 transverse eye diameters as seen from above. Frontoclypeal suture deep, distinctly arcuate. Clypeus trapezoidal, narrowing apically, sides almost straight, apex truncate and slightly emarginate, margins reflexed; surface feebly and sparsely aciculate, irregularly punctate; punctures small to large (large near basal and apical angles), shallow, larger punctures ocellate-umbilicate; a short, deeply impressed, diagonal furrow just medial of each basal angle extends laterally from near base. Scutellum triangular, impunctate. Elytra: Discal area with 8 rows of punctures; punctures large, moderately deep, most ocellateumbilicate (ring of puncture c-shaped, open posteriorly). Row 1 (next to suture) with punctures in a single file, some confluent apically; row 2 broad, irregularly punctate; rows 3-4 regularly punctate, closely adjacent; row 5 narrower than row 2 impunctate in basal $2 / 3$, regularly punctate in apical third; rows 6-7 regularly punctate, closely adjacent, arcuate; row 8 with 7 punctures at middle and 1 at apex, otherwise impunctate. Sides similar 

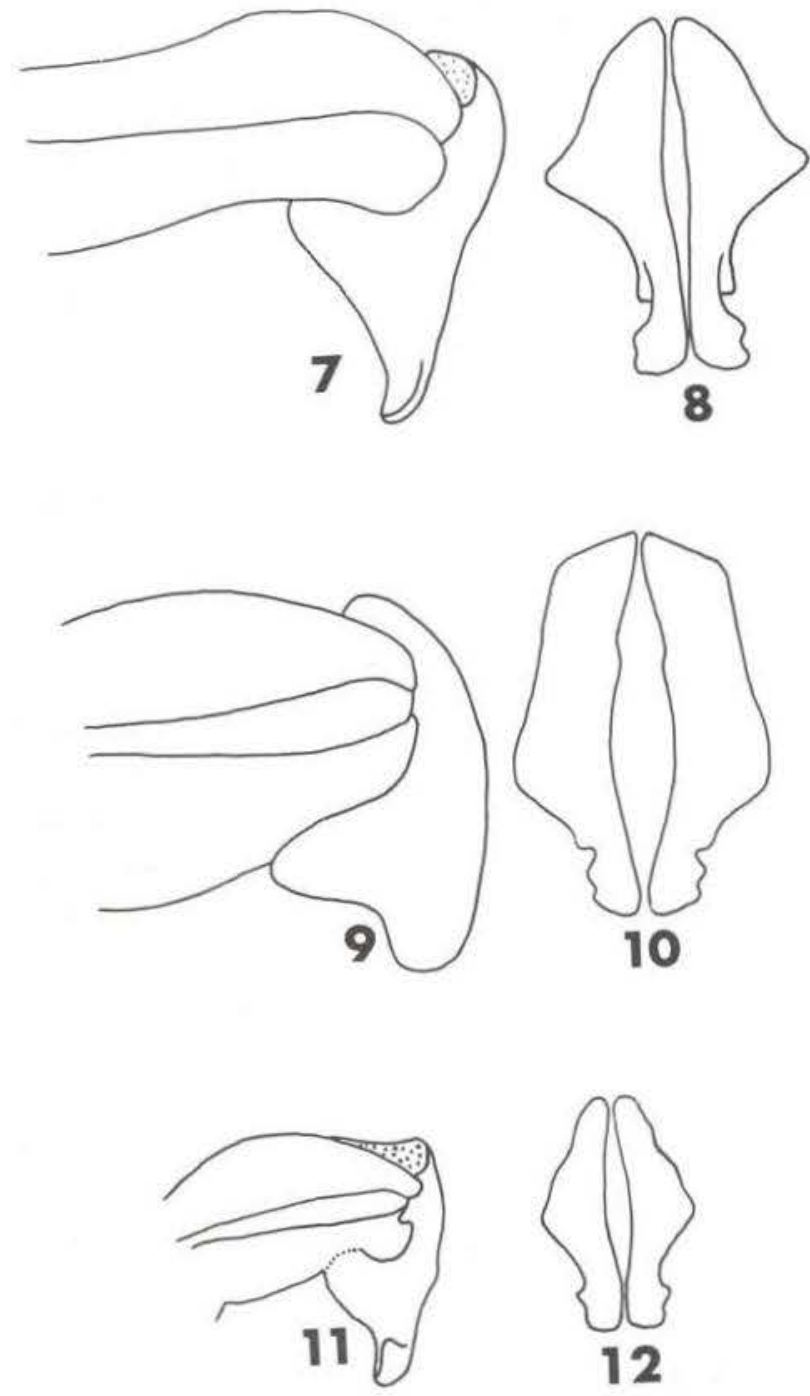

Figs 7-12 - Lateral and caudal views of male genitalia. Figs. 7-8 - Stenocrates amazonicus. Figs. 9-10 S. ariasi. Figs. 11-12 - S. laceyi.

to disc; 2 regular rows of punctures behind humerus, followed laterally by a row of irregular punctures, 2 rows of regular punctures, and a sparsely punctate row of irregular punctures next to lateral margin. Pygidium: Surface moderately densely punctate; punctures large, moderately deep, ocellate-umbilicate. Genitalia: Figs. 9-10

ALLOTYPE - Female. Length $20.0 \mathrm{~mm}$; greatest width $11.0 \mathrm{~mm}$. As holotype except in the following respects: Head: Front rugopunctate just behind frontoclypeal suture. Clypeal apex lacking emargination; surface rugose. Pronotum: Punctures lacking emar- gination; surface rugose. Pronotum: Punctures small, sparse either side of center of disc; posterior angles with only a few large punctures, apical angles lacking large punctures. Diagonal furrow near base absent.

VARIATION - Males (1 paratype): Length $20.0 \mathrm{~mm}$; greatest width $11.0 \mathrm{~mm}$. Head: Front a little more densely punctate than holotype. Frontoclypeal suture only feebly arcuate. Pronotum: A few large punctures in center behind each eye; diagonal furrow near base present but extremely short. Elytra: Row 5 completely impunctate; row 8 with a few punctures in basal third.

Females (2 paratypes): Length 21.0-22.0 $\mathrm{mm}$; greatest width $11.0-11.5 \mathrm{~mm}$. Head: Front sparsely to moderately punctate. Frontoclypeal suture broad, not arcuate. Pronotum: Large punctures slightly more abundant in 1 paratype to moderately dense in posterior half of each lateral third and in apical angles of second paratype. Furrow near base effaced in 1 specimen; represented by a small, weak depression in second specimen. Elytra: Row punctate in apical third, one specimen with a few scattered punctures on rest of row. Pygidium: A small area near apex sparsely punctate in both females.

Discussion - The male genitalia of Stenocrates ariasi are diagnostic for this species.

FTYMOLOGY - This species is named in honor of $\mathrm{Dr}$. Jorge R. Arias, Chief of the Division of Medical Sciences of the Instituto Nacional de Pesquisas da Amazônia in Manaus in grateful acknowledgement of his invaluable assistance to my work with Scarabaeidae in Brazil.

\section{Stenocrates laceyi, new species} (Figs, 11-12)

TYPE MATERIAL - Holotype male, labeled "Brasil: Amazonas, rio Demini, ilha Meruim, IV-11-15-1978, L. A. Lacey". Allotype female, labeled "Brasil: Amazonas, rio Demini nr. equator, IV-10-1978, L. A. Lacey". Single male paratype with same data as allotype. Types deposited at the Instituto Nacional de Pesquisas da Amazônia (INPA). Paratype deposited in the Brett $C$. Ratcliffe collection (BCRC). 
HOLOTYPE - Male. Length $13.5 \mathrm{~mm}$; greatest width $8.3 \mathrm{~mm}$. Color black. Head: Front coarsely rugo-punctate. Interocular width 2.5 transverse eye diameters as seen from above. Frontoclypeal suture slightly curved, broad, shallow, anterior edge effaced at midpoint. Clypeus trapezoidal, narrowing apically, sides weakly arcuate, apex truncate, margins reflexed; surface transversely rugose. Pronotum: Length-width ratio 2:3. Surface entirely punctate; punctures moderate in density, moderately large (some small near anterior margin), moderately deep. Scutellum triangular, sparsely punctate; punctures small. Elytra: Discal area with 8 rows of punctures; punctures large, moderately deep, ocellate (ring of puncture c-shaped, open behind). Row 1 (next to suture) with punctures in a single line, becoming confluent apically; row 2 broad, irregularly punctate; rows 3-4 regularly punctate, closely adjacent; row 5 slightly narrower than row 2, impunctate in basal half, punctures in apical half nearly regular; rows 6-7 regularly punctate, closely adjacent, arcuate; row 8 subequal to row 5 in width, irregularly punctate. Sides similar to disc; 2 regular (but somewhat indistinct) rows of punctures behind humerus, followed laterally by an indistinct row of irregular punctures, 2 rows of regular punctures, and a row of irregular punctures next to lateral margin. Pygidium: Surface densely punctate; punctures large, ocellate-umbilicate. Genitalia: Figs. 11-12.

ALLOTYPE - Female, Length $13.5 \mathrm{~mm}$; greatest width $7.5 \mathrm{~mm}$. Agrees with holotype in all respects.

VARIATION - Males (1 paratype): Length $13.0 \mathrm{~mm}$; greatest width $7.3 \mathrm{~mm}$. The single paratype does not differ significantly from the holotype.

DISCUSSION - The male genitalia of this species is diagnostic, and will separate it from all others.

These specimens were taken at black light located on the roof of a boat moored about $10 \mathrm{~m}$ from shore in an area of varzea forest.

ETYMOLOGY - This species is named after its collector, Dr. Lawrence A. Lacey.

\section{Stenocrates haackae Ratcliffe}

Stenocrates haackae Ratcliffe (1977) was described from only two male specimens, but a series of nine males and ten females have recently been collected from Camará and Codajás on the rio Solimōes as well as a single male from Manaus on the rio Negro.

The following brief comments, based on this new material, are given to better define the species. The males vary only a little from the original description in the following respects: front with punctures either side of middle greatly reduced in all but one specimen; clypeus with rugosity as holotype to reduced; pronotum with disc virtually impunctate, punctures in area of basal angle reduced; pygidium as type to densely punctate. punctures strongly ocellate. The females are similar to the males except in the following respects: length 19.0-21.0 mm; greatest width $10.0-11.0 \mathrm{~mm}$; front and clypeus as type to punctures and rugosity reduced.

\section{Stenocrates popei Endrödi}

Stenocrates popei Endrödi (1971) was described from Guyana based on two male specimens. It is here reported from Brazil with the following data: State of Amapá, Serra do Navio, 7, 15, and 19 July 1961, J. and B. Bechyne collectors, four males and two females. Serra do Navio is not far from the Guianas, and the Brazilian records are not really unexpected; they reflect increased collecting where once there was little or none.

The males do not vary appreciably from Endrödi's original description, and the females do not differ significantly from the males at hand.

\section{Resumo}

Seis novas espécies de Stenocrates (Coleoptera: Scarabaeidae: Dynastinae) do Brasil são descritas: S. rionegroensis, S. varzeaensis, S. inpai, S. amazonicus, S. ariasi, e S. laceyi. As fêmeas de S. haackae Ratcliffe e de S. popei Endrödi são relatados pelá primeira vez e caracterizadas brevemente. Stenocrates popei é catalogada no Brasil e constitui um novo registro no país. 


\section{LITERATURE CITED}

ENDRÖDI, S

1966 - Monographie der Dynastinae (Coleoptera, Lamellicornia). Tiel I. Ent. Abh. Mus, Tierk. 33:1-460.

1967 - Drei neue Arten der Tribe Cyclocephalini (Col., Dynastinae). Fol. Ent. Hung. 20(1):1-8.

1969 - Einige neue Cyclocephalini und Pentodontini (Coleoptera: Dynastinae). Acta Zool. Acad. Sci. Hung., 15(1-2):31-42.

1971 - Uber neue und bekannte Dynastinen (Col., Melolonthidae). Fol. Ent. Hung. 24(14):179-184.
1973 - Einige Dynastinen-Arten (Coleoptera: Melolonthidae) aus Bolivien. Opusc. Zool. Budapest, 12(1-2):57-61.

RATCLIFFE, B.C

1975 - A revision of the genus Strategus (Coleoptera: Scarabaeidae). Bull. Univ. Nebraska St. Mus, 10(3):93-204.

1977 - Four new species of Neotropical Cyclocephalini (Coleoptera: Scarabaeidae). Acta Amazonica, 7(3):429-434.

(Aceito para publicação em 05-06-78) 